\section{Standard Jones and Modified Jones: An Earnings Management Tutorial}

\author{
Jones Padrão e Jones Modificado: Um Tutorial de Gerenciamento de \\ Resultados
}

\author{
Cristiano Machado Costa 10 \\ José Mauro Madeiros Velôso Soares*1
}

\section{ABSTRACT}

Context: measurement of earnings management usually requires multistep models for computation. After examining the literature through bibliometrics studies, literature review, and research databases, we found that the Standard Jones model and its subsequent modifications are those that have more prominent use. Much of this research is potentially interesting for business theories related to earnings quality and accounting manipulation; however, it is difficult to be understood by junior researchers and practitioners, because they are not clearly described in the literature or the steps may be easy to confuse. Objective: in this tutorial, we present several key concepts about earnings management and explain, step by step, how to measure it. Method: our tutorial considers measurement using the following models: Standard Jones, Modified Jones, Modified Jones with return on assets (ROA), and Modified Jones using Cash Flows and Accruals Reversals. Conclusions: our main contribution with this tutorial is to provide a step-by-step guide for future studies, so that they can be more comparable with each other when using measurement methods of earnings management.

Keywords: earnings management; Standard Jones; Modified Jones; ROA; cash flow and reversals.

\section{RESUMO}

Contexto: a mensuração do gerenciamento de resultados usualmente requer modelos baseados em múltiplos passos para computaçáo. Após consultar a literatura por meio de estudo bibliométrico, revisão da literatura e bases de dados de pesquisa, identificamos que o modelo Standard Jones e suas subsequentes modificaçóes são os que apresentam uso mais proeminente. Muito desta pesquisa é potencialmente interessante para as teorias sobre negócios associadas à qualidade dos lucros e manipulaçẫo contábil; porém, é difícil de ser compreendida por pesquisadores iniciantes e profissionais, pois os passos podem ser facilmente confundidos ou não são claramente descritos pela literatura que os utiliza. Objetivo: neste tutorial, apresentamos vários conceitos-chave sobre o gerenciamento de resultados e explicamos passo a passo como mensurá-los. Método: nosso tutorial considera a mensuraçáo utilizando os modelos Jones Padrão, Jones Modificado, Jones Modificado com Retorno sobre o Ativo e Jones Modificado considerando Fluxo de Caixa e Reversão dos Accruals. Conclusóes: nossa principal contribuição com este tutorial é estabelecer um passo a passo que norteie futuras pesquisas, para que estes estudos possam ser mais comparáveis uns aos outros quando utilizam os métodos de mensuração de gerenciamento de resultados.

Palavras-chave: gerenciamento de resultados; Jones Padrão; Jones Modificado; fluxo de caixa e reversóes. 


\section{INTRODUCTION}

Financial statements should adequately portray summaries to distinguish differences in companies' financial and economic positions (Healy \& Wahlen, 1999). However, in the literature, accountants and financial economists have recognized that reported results may be managed by a variety of idiosyncratic contexts inherent in accounting choices (Cornett, McNutt, \& Tehranian, 2009). Discretionary accounting choices may misrepresent or provide more appropriate private information in financial statements (Menicucci, 2020).

Managers use discretion in accounting reports. Their accounting decisions are reflected in the firm's earnings measures (Walker, 2013). A significant part of the research concerning earnings management has used the concept of quantity of discretionary accruals as a measurement of how managed the earnings were. The definition of accruals indicates that their use temporarily improves or reduces reported earnings, since their composition is not immediately reflected in cash flows, and often depends on managerial judgment (Bergstresser \& Philippon, 2006).

Earnings management always occurs, and it is difficult to list how it occurs specifically. El Diri (2017) lists 19 quantitative and qualitative proxies for earnings management measurement. According to El Diri (2017), models may measure earnings management using: accruals (e.g., Dechow, Sloan, \& Sweeney, 1995; Jones, 1991; Kang \& Sivaramakrishnan, 1995; Kothari, Leone, \& Wasley, 2005; Pae, 2005; Paulo, 2007), real activities (e.g., Eldenburg, Gunny, Hee, \& Soderstrom, 2011; Gunny, 2010; Roychowdhury, 2006), or combined models (e.g., Zang, 2012). There can be also studies using qualitative research approaches (e.g., De Jong, Mertens, Poel, \& Dijk, 2014).

Earnings management is not observable in practical ways or directly measured. The main focus of the earnings management literature is on accruals earnings management, and most of the research propose models to measure them (El Diri, 2017). However, to distinguish discretionary and non-discretionary accruals is problematic. According to the literature (Magro, Lavarda, \& Klann, 2019; Sun, Salama, Hussainey, \& Habbash, 2010), the most prominent model is Modified Jones (Dechow et al., 1995).

Although widely accepted, handled, and discussed, it is possible to find concerns in academic forums about the method, different treatments regarding its operation, and implementations aiming at more accurate measurement of discretionary accruals (e.g., Kalifekh, 2018; Potharla, 2018; Qamhan, 2018). More recent research based on Modified Jones model considers it on its early forms (Dechow et al., 1995), with further modifications considering ROA
(Kothari et al., 2005), or accruals reversals (Pae, 2005), for example.

There are several useful introductions to earnings management models and methods in business literature, but none of them is a tutorial on measuring and discussing the model and its derivations directly. In this paper, we aim to elucidate and explain, step by step, the procedure to measure earnings management by Jones Modified, Jones Modified with ROA, and Jones Modified Considering Reversals models. Additionally, we discuss and explain the biases, possible deficiencies, the major limitations, and empirical issues relevant to the metrics' estimates. Most of the highimpact research on earnings components that we present is based on two recent books about earnings management and earnings quality (El Diri, 2017; Menicucci, 2020).

Our paper contributes to the literature in the following ways. First, some authors use models based on Standard Jones, without clarifying or providing supplementary operational files; differently, we discuss step by step the operationalization of these models. Second, we provide comments and additional specification alternatives to avoid limitations according to each sample and show that researchers should interpret their earnings management proxy measures with caution. Lastly, our study suggests that more research is needed to discuss and teach step-bystep approaches and to develop alternatives according to idiosyncrasies.

The database used in this research is publicly available in the supplementary materials. The dataset corresponds to financial data of companies listed in Brasil, Bolsa, Balcão (B3) that are not in the financial sector. Sample data were obtained for the period from 2009 to 2018, excluding companies whose statements did not present all the data required for the calculations for all years. The sample resulted in 249 companies in the tutorial period.

\section{EARNINGS MANAGEMENT LITERATURE}

Earnings management literature relates to a wide range of topics such as: analyst coverage (Martinez, 2011; Yu, 2008), asset valuation (Caruso, Ferrari, \& Pisano, 2016), audit issues (Barghathi, Collison, \& Crawford, 2018; Silvestre, Costa, \& Kronbauer, 2018), corporate governance (Cornett et al., 2009; Xie, Davidson, \& DaDalt, 2003), convergence to IFRS (Grecco, 2013), debt issues (Coelho \& Lopes, 2007; Costa, Matte, \& Monte-Mor, 2018; Dutzi \& Rausch, 2016; Nardi, Silva, Nakao, \& Valle, 2009), economic cycle (Filip \& Raffournier, 2014), gender characteristics (Gull, Nekhili, Nagati, \& Chtioui, 2018; Harris, Karl, \& Lawrence, 2019; Liu, Wei, \& Xie, 2016), linguistics (Lo, Ramos, \& Rogo, 2017), securitization issues (Barth \& Taylor, 2010; Camara \& Galdi, 2013), 
fixed costs (Kama \& Weiss, 2013; Silva, Zonatto, Magro, \& Klann, 2019), taxes issues (Lin, Lu, \& Zhang, 2012; Paulo, Martins, \& Corrar, 2007), and tone analysis (Huang, Krishnan, \& Lin, 2018).

Many of these articles have used discretionary accruals to estimate earnings management. Much of the literature has used models based on the Standard Jones and Modified Jones due to the wide international acceptance and cross-country studies. Definition and descriptions of accruals fundaments and composition may be reviewed in Richardson, Sloan, Soliman, \& Tuna (2005), and from preparers' perception in Parfet (2000).

\section{JONES MODELS' ESTIMATION: A TUTORIAL}

\section{Standard Jones model}

The original context of the Jones model (Jones, 1991) was to test whether managers managed earnings to shape accounting numbers to obtain benefits from important relief regulation. Its implementation to distinguish the discretionary accruals from total accruals is inherent to the context. She argues that the earnings interest variable is the earnings before taxes, because managers use some accruals-based decisions to minimize the earnings that will be reported. The definition of total accruals, in model, is presented in Equation 1:

$\mathrm{TA}_{i t}=\Delta$ CurrentAssets $_{i t}-\Delta$ Cash $_{i t}-\Delta$ CurrentLiabilities $_{i t}-\mathrm{DAE}_{i t}$

where $\mathrm{TA}_{i t}=$ total accruals in year $t$ for firm $i$; CurrentAssets ${ }_{i t}$ $=$ current assets in year $t$ less current assets in year $t-1$ for firm $i ; \Delta$ Cash $_{i t}=$ cash in year $t$ less cash in year $t-1$

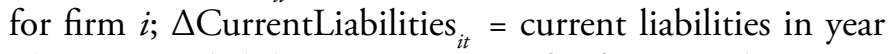
$t$ less current liabilities in year $t-1$ for firm $i$; and $\mathrm{DAE}_{i t}=$ depreciation and amortization expense in year $t$ for firm $i$.

Jones (1991) calculates the total accruals without considering the exclusion of long-term debt and income tax portion due to the lack of data in the database used (Compustat). The variables necessary for the calculation of $\mathrm{TA}_{i t}$ are available in the financial statements, such as balance sheet, income statement, and cash flow statement. The explanation for using balance sheet information is based on the link between changes in the working capital accounts and the accruals of income and expenses in the income statement (Paulo, 2007).

Often, the financial databases are not adjusted in order. In an attempt to generate lagged variables or perform mathematical operations, an invalid syntax error is reported. Stata $^{\circledR}$ software has a quick solution for organizing data by company and chronological order, for example. The command sort and the variables list arrange all observations based on values in ascending order (StataCorp, 2019). Before any computation, the researcher has to make sure that the dataset is sorted by company and period.

Optionally, to avoid outliers' shortcomings in the sample, we recommend apply a winsorization technique before starting this tutorial steps. Winsorization corresponds to the most usual technique to mitigate errors in estimates by financial literature (Adams, Hayunga, Mansi, Reeb, \& Verardi, 2019). For other ways to identify and treat univariate and multivariate data, see Adams, Mansi, Reeb and Wald (2019).

On the first use, it is necessary to install the supplementary package on Stata ${ }^{\oplus}$. For this, type: ssc install winsor. This package proposed by Cox (2006) works to generate a transformation of the required variable and the syntax command is: winsor variable, gen(new_variable) $p(0.1)$. The number in parentheses, after $p$ (between 0 and $0.5)$, specifies the observations called to modify in each data tail. Another implementation by Yu-jun (2014) can be used to replace a variable with the same name. The syntax to install is ssc install winsor2. Winsor2 works in a similar way to Winsor and allows multiple variables to be used at once. The command syntax is: winsor2 variable_list, replace cuts(1 99). For our database, we use:

winsor2 Assets Current_assets Cash Account_Reicevables Inventories ppe Current_liabilities STD noncurrent_assets Depreciation net_income CFO, replace cuts(1 99)

These accounting variables are explained in the database throughout the article. Once the dataset is sorted by company and year, a practical way to calculate the variations is to use the by prefix before the function to generate the variable: by group_variable : command_syntax. The word gen refers to generate, subsequently the variable is required, followed by equal $(=)$, the name of new variable with the command $l$. to calculate lags. The syntaxe $l$. it needs to be defined whether the data is a time series or a panel. In our case, the definition would be by the syntax: xtset Firm_id Year, year.

For our database, we use:

by Firm_id : gen lag_Current_assets $=$ I.Current_assets

by Firm_id : gen lag_Cash $=$ I.Cash

by Firm_id : gen lag_Current_liabilities $=$ I.Current_liabilities

To calculate in Stata software and generate a new variable, the generate command is used. On the command line, it is necessary to define the generation of a new variable, the name of this new variable, and the mathematical criteria to generate. If the panel definition or time series is used, 
delta variables can be generated by the $d$ command, instead of the equation in the syntax.

In our database, we used the following commands to generate the three variations required to calculate total accruals in Equation 1:

gen delta_current_assets = (Current_assets - lag_Current_ assets) orgen delta_current_assets $=\bar{d}$. Current_assets

gen delta_cash $=$ d.Cash

gen delta_current_liabilities $=d$.Current_liabilities

This step is necessary for all other variables that need to be generated mathematically. Throughout the tutorial, we will repeat this logic each time we are required to compute a variation from one year to another. To compute total accruals, we simply create a new variable in dataset, using the definition in Equation 1. The command for our database is:

gen JonesTotalAccruals_t $=$ delta_current_assets - delta_cash - delta_current_liabilities - Depreciation

Because we assume that discretionary accruals are a part of total accruals, after calculating the total accruals for the period, the next step in Standard Jones model is to estimate discretionary accruals. The central argument for not adjusting is related to the missing values in the original database used to perform the model, while maximizing the number of observations. The next step after calculating the total accrual is to estimate the coefficients to be used in calculation of discretionary and non-discretionary accruals. To perform this step we used Equation 2:

$$
\left(\frac{\text { TAit }}{A_{\mathrm{it}-1}}\right)=\alpha_{0}+\alpha_{1}\left(\frac{1}{A_{\mathrm{it}-1}}\right)+\beta_{1}\left(\frac{\Delta \mathrm{R}_{\mathrm{it}}}{\mathrm{A}_{\mathrm{it}-1}}\right)+\beta_{2}\left(\frac{\mathrm{PPE}_{\mathrm{it}}}{\mathrm{A}_{\mathrm{it}-1}}\right)+\epsilon_{\mathrm{it}}
$$

where TAit $=$ total accruals in year $t$ for firm $i ; \Delta \mathrm{R} i t=$ revenues in year $t$ less revenues in year $t-1$ for firm $i$; PPEit $=$ gross fixed assets, plant, and equipment in year $t$ for firm $i$; Ait $-1=$ total assets in year $t-1$ for firm $i$; and Eit $=$ error term in year $t$ for firm $i$. Note that all variables are based on the variable TAit. This is because this treatment avoids the presence of heteroskedasticity in the distribution, because it is expected, from the variable TAit, to have a theoretical association with the variance of the error term (Jones, 1991). The next step is to apply the by command to generate TAit:

by Firm_id : gen lag_Assets $=$ I.Assets

To estimate Equation 2, two steps are necessary. Generate the lagged revenue variable:

by Firm_id : gen lag_Revenue $=$ I.Revenue

and generate $\Delta \mathrm{R} i$ :

gen delta_Revenue $=d$.Revenue
The step before performing the regressions is to scale each variable by the total assets of the previous period:

gen TA_jones1991 $=$ JonesTotalAccruals_ $t /$ lag_Assets

gen InverseAT_jones1991 = $1 /$ lag_Assets

gen delta_Revenue jones1991 = delta_Revenue / lag_Assets

gen PPE_jones1991 = ppe / lag_Assets

In order to estimate Equation 2 coefficients and prediction error, time-series data by ordinary least squares regression are performed as proposed by Jones (1991). However, to avoid violating the presumption of uncorrelated errors, subsequent studies have adopted a cross-sectional model by industry sector and year (El Diri, 2017). In this tutorial, we adopted the indication and the coefficients of Equation 2, necessary to determine normal accruals.

The 'asreg' package estimate cross-sectional regressions or regressions by a grouping variable (Shah, 2018). In the first time using 'asreg' on command line, type ssc install asreg to install the package. To estimate the regressions by group, we must have variables in the database to define years and industry sectors. El Diri (2017) shows this is another limitation, as, within the same sector, there is often no homogeneity. Therefore, the solution is not perfect, but minimizes the problem.

At this point, we rename the variables to make the inference. We use the terminology, including Jones1991 at the end of each variable to organize. When we have more than one dependency, by is replaced by bys in the command syntax. After the by prefix, groups variables and command syntax, options are required: a comma (,) followed by se and fit. After the commas, the optional item noconstant may be placed to run the regression without the constant term. In both, the first and the second commands, se and fit, generate, in addition to the coefficients, columns of variables with the standard error, the error term, and the fitted value. The command step to run the 'asreg' regressions is:

bys B3_sector Year: asreg TA_jones1991 InverseAT_jones1991 delta_Revenue_jones1991 PPE_jones1991, se fit

However, for some countries like Brazil, where the capital market is not well developed, the use of sector and year approach may lead to small samples. In order not to compromise the quality of the results obtained, one option is to make the calculation considering only the year. Considering only the year means that the idiosyncratic characteristics of each sector are not captured. However, even within the same sector, companies' core business can be very different, and the trade-off of considering only the year as a group can be a more effective measure than using year and industry. The use of the 'year and industry sector' approach implies regression models with only three, four, or 
seven companies, with relevant distinctions between their standards, although from the same industry. Countries have their singularities, so we approach and propose ways to get around this, once methodologies already consolidated in the literature have greater acceptability by the scientific community.

The operationalization of the models using only the year and not the sector just suppresses the variable that defines the industry sector from the command syntax. In our database example, the command to run all regression for all years is:

by Year : asreg TA_jones1991 InverseAT_jones1991 delta_ Revenue jones1991 PPE jones1991, se fit

By default, every time the asreg command is used, new columns are created in the Stata ${ }^{\oplus}$ worksheet. Each new variable is created according to the called syntax, group by group. If it is useful or necessary to save these terms and run more than one of the ways discussed, it is required to rename (and/or drop) the default variables. This is because to create new variables to run the syntax of such command, Stata ${ }^{\circ}$ understands that the variables will be created in duplicate.

A relevant discussion is the use or not of the constant term. Although some authors (e.g., Costa, Matte, \& MonteMor, 2018; Silva et al., 2019; Vasconcelos, Reis, Miyashiro, \& Paulo, 2008) do not use it, we will indicate to use the results generated with the term. The absence of the constant implies attributing that the origin of the line formed by the observations is point zero. The inclusion indicates that there is variability among the other variables; however, part of this variability is constant for each industry sector in a given year $i$, or at least in each year when using only the year approach.

According to Hahn (1977), to pass through the origin point, the mean of variable is equal to zero when the independent variables are equal to zero. Due to the composition of the dependent variable and theoretical assumptions, this is not always true.

In real-life problems, some circumstances require regressions from the origin point, but this is rarely discussed (Eisenhauer, 2003). For example, in researches on earnings management measured by Jones model, the utilization is mixed, but not discussed. Regarding earnings management measurement, a critical point of forcing the regression line through the origin is related to error term, whose mean usually is non-zero. The explanation for the occurrence is that the forced model is generally inconsistent with the best fit of the measures (Eisenhauer, 2003).

The inclusion of the constant term, although other researches do not use it, improves the control of two problems: (a) heteroskedasticity, that is not controlled by the use of scaled variables in asset, and (b) the problem of omission of size control by the scale of the variables (Kothari et al., 2005).

Regarding the estimated parameters, according to Jones (1991), we should expect a negative sign in coefficients of PPE variables, because depreciation expenses are correlated to PPE and contribute negatively to decrease income, for the reason of decreasing the accrual; for the other variables, there is no obvious sign, as they refer to variations. Discretionary accruals are the absolute values of the residuals from Equation 2. To generate this, it is necessary to generate a new variable:

\section{gen wc_abs_DACC $=$ abs(_residuals)}

This command must be used right after run the respective asreg. This happens for the same reason that we commented on dropping: Stata ${ }^{\circledR}$ creates, by default, variables with standardized names, preventing other items with the same name from being built in duplicate. The items $w c$ residuals and $n c$ cresiduals correspond to the renamed variable_residuals after run the regressions with and without the constant.

To save this or any other among the results obtained, or a summary of the results, it is often suggested to have them as a file that allows copying (like RTF, .doc, or .docx). For this, our recommendation in Stata ${ }^{\circ}$ is through the use of the 'asdoc' package. The asdoc command output results in Word or RTF formatted tables as in Shah (2018). To use it is necessary to install it in the first time run: ssc install asdoc. To run, asdoc works similarly to the prefix, but accepts other prefixes. To save summary of discretionary accruals, the syntax is, for example, to summarize discretionary accruals variables by year and sector and generate results archive file with the command:

asdoc by Year B3_sector, sort : summarize wc_abs_DACC nc_ abs_DACC, detail

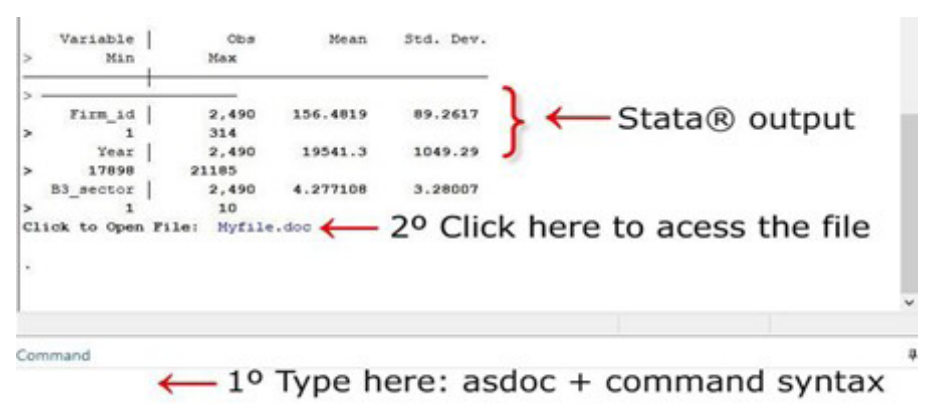

Figure 1. An example of asdoc uses output.

This is one of asdoc output from Stata that shows the output of the command and the .doc table file. 
The same can be done for any other syntax of interest to the individual. With the graphics, Stata allows them to be edited and saved directly in the software - for review, see StataCorp (2019). In this case, asdoc requests a file, by Year B3_sector sets the variables that separate the groups, sort organizes observations of current variables in ascending order, summarize presents number of observations, minimum, maximum, mean, and standard deviation of variables, and wc_abs_DACC and nc_abs_DACC represent discretionary accruals with and without constant term. Comma (,) is addressed to additional information and detail to input variance, skewness, and kurtosis.

After all the steps detailed above, it is possible, at this point, to state that a measure of discretionary accruals is available, with its due adjustments. The interpretation of discretionary accruals in relation to the quality of earnings is referenced to the absolute value of measured accruals; lower values are used when the quality of earnings is higher (Menicucci, 2020). You should be able to generate the Table 1 statistics.
The limitations of the initial Jones (1991) model are important, and some of them are circumvented more intuitively by other implementations. The principal limitation addressed is related to other expenses (discretionary and non-discretionary) that are not contemplated in total accruals explanation. This approach implies a theoretical and pragmatic problem from omitted variables (El Diri, 2017). Furthermore, in the model described in the seminal work, the equation has no intercept, which implies a bias in the estimated coefficients (Paulo, 2007).

Additionally, the limitation of the calculation performed by sector and by year is explained by the limitation of data, which do not allow a better company-by-company estimate. Therefore, it is implicit that the sectors adopt similar management strategies over time. To avoid errors in earnings management, measurement by Jones model should abstain from small samples, more specifically type II errors (El Diri, 2017).

Table 1. Example of summary statistics of variable wc_abs_DACC per year from public utilities industry sector.

\begin{tabular}{|c|c|c|c|c|c|c|}
\hline Year & Industry sector & Mean & Std. Dev. & Variance & Skewness & Kurtosis \\
\hline 2010 & Public utilities & 0.264081 & 0.212606 & 0.045202 & 0.835571 & 3.445516 \\
\hline 2011 & Public utilities & 0.177435 & 0.106435 & 0.011329 & 1.900128 & 8.798464 \\
\hline 2012 & Public utilities & 0.074823 & 0.114205 & 0.013043 & 2.294486 & 7.659302 \\
\hline 2013 & Public utilities & 0.079828 & 0.07876 & 0.006203 & 2.354677 & 10.43627 \\
\hline 2014 & Public utilities & 0.149612 & 0.380005 & 0.144404 & 5.582921 & 35.02707 \\
\hline 2015 & Public utilities & 0.092788 & 0.132447 & 0.017542 & 3.266309 & 13.79829 \\
\hline 2016 & Public utilities & 0.103835 & 0.257489 & 0.066301 & 6.105255 & 39.7623 \\
\hline 2017 & Public utilities & 0.746531 & 0.080336 & 0.006454 & 2.065963 & 7.185377 \\
\hline 2018 & Public utilities & 0.068928 & 0.764205 & 0.00584 & 2.256641 & 9.00917 \\
\hline
\end{tabular}

Note. This table shows all summary of variable wc_abs_DACC. Source. Costa, C. M., \& Soares, J. M. M. V. (2021). Data for: Standard Jones and Modified Jones: An earnings management tutorial" published by RAC-Revista de Administraçấo Contemporânea. Mendeley Data, V2. https://doi.org/10.17632/c939cpg956.2

\section{Modified Jones models}

\section{Modified Jones model}

The Modified Jones model (Dechow et al., 1995) is described by the authors as a modified version of the Jones (1991) model. The central point of Modified Jones is to improve the measurement of discretionary accruals. In this model, the authors solve an elementary problem: revenues can be managed by companies, and this effect can be controlled if the possibility of manipulating credit sales is taken into account (Paulo, 2007). To mitigate this limitation of the Jones model, a variety of studies have attempted to replace it by adding omitted variables, eliminating extreme observations, or applying completely different estimators to solve the shortcomings (El Diri, 2017). A comparison between the models, Jones versus Modified Jones, depends on how earnings management is expected to occur: if earnings management occurs via revenue or debt accounts (Peasnell, Pope, \& Young, 2000).

To estimate earnings management by Modified Jones, the first step is similar to Standard Jones, as described in the previous section, but Equation 3 includes a new variable: STDit. 


$$
\mathrm{T} A_{i t}=\Delta C \text { urrentAssets }_{i t}-\Delta C \operatorname{Cash}_{i t}-\Delta C \text { urrentLiabilities }_{i t}+\Delta \mathrm{STD}_{i t}-D A E_{i t}
$$

where TAit $=$ total accruals in year $t$ for firm $i$; $\Delta$ CurrentAssetsit $=$ current assets in year $t$ less current assets in year $t-1$ for firm $i$; Cashit = cash in year $t$ less cash in year $t-1$ for firm $i$; $\Delta$ CurrentLiabilitiesit $=$ current liabilities in year $t$ less current liabilities in year $t-1$ for firm $i$; $\Delta \mathrm{STD} i t=$ debt included in current liabilities in year $t$ less debt included in current liabilities in year $t-1$ for firm $i$; and DAE $i t=$ depreciation and amortization expense in year $t$ for firm $i$.

The steps are the same to generate the variables, since in the first part the equation for calculating the total accruals is similar. If created for the Standard Jones model, these steps are no longer needed, since the variable with the total accruals must already be in the Stata ${ }^{\circledR}$ environment, except for the variable STD.

by Firm_id : gen lag_STD $=$ I.STD

gen delta_STD $=$ d.STD

gen MdfTotalAccruals_t $=$ delta_current_assets - delta_cash delta_current_liabilities + delta_STD - Depreciation

Then, after calculating the total accruals, it will be necessary to estimate the normal accruals. The parameters $(\alpha$, $\beta 1$, and $\beta 2$ ) are estimated according to Equation 2, from the Standard Jones model. Like the Standard Jones model paper (Jones, 1991), the Modified Jones (Dechow et al., 1995) runs the regressions in time series specification. However, as explained for the Standard Jones model estimate, it is suggested the use of the cross-sectional approach.

As we change the total accruals variable, the steps to run it again need to include the newly created variable, with the label MdfTotalAccrualst. The steps to do this and then run the regressions are:

gen MdfjonesTACC $=$ MdfTotalAccrualst $/$ lag_Assets

bys B3_sector Year : asreg MdfjonesTACC InverseAT_jones 1991 delta_Revenue_jones1991 PPE_jones1991, se fit

Stata ${ }^{\oplus}$ does not accept the creation of many variables with the same name. If it is required, change the names of the variables according to the needs of each one. The estimated coefficients are used to estimate non-discretionary accruals by Equation 4. In the Modified Jones model, the results of the equation parameters are used to calculate nondiscretionary accrual, since with including the variable $A R_{i t}$ discretionary accruals cannot be calculated directly by the residual.
$\mathrm{N} A_{i t}=\widehat{\alpha_{0}}+\widehat{\alpha_{1}}\left(\frac{1}{A_{t-1}}\right)+\widehat{\beta_{1}}\left(\frac{\Delta R_{i t}-\Delta A R_{i t}}{A_{t-1}}\right)+\widehat{\beta}_{2}\left(\frac{P P E_{i t}}{A_{t-1}}\right)+\epsilon_{i t}$

where NAit $=$ normal accruals in year $t$ for firm $i$; $\Delta i t=$ revenues in year $t$ less revenues in year $t-1$ for firm $i$; $\Delta \mathrm{AR} i t=$ accounts receivables in year $t$ less accounts receivables in year $t-1$ for firm $i$; PPEit $=$ gross fixed assets, plant, and equipment in year $t$ for firm $i$; Ait $-1=$ total assets in year $t-1$ for firm $i$; and $\varepsilon i t=$ error term in year $t$ for firm $i$. To estimate in Stata ${ }^{\circ}$, the default command without renaming the variables generated is:

\section{by Firm_id : gen lag_Account_Reicevables = I.Account Reicevables \\ gen delta_AR $=$ d.Account_Reicevables}

gen scaled_delta_AR $=$ delta_AR / lag_Assets

gen MdfNAit = _b_cons + (b_InverseAT_jones1991 * InverseAT_jones1991) + (_b_delta_Revenue_jones1991 * ( delta_Revenue_jones1991 - scaled_delta_AR ) ) + (_b_PPE_ jones1991 * PPE_jones1991) +_residuals.

After creating the new variable - normal accruals (NAit) - using Equation 5, discretionary accruals are calculated as:

$\mathrm{D} A_{i t}=\frac{T A_{i t}}{A_{i t-1}}-\mathrm{N} A_{i t}$

To generate discretionary accruals, after generating normal accruals, only a command is needed:

gen MdfDACC = MdfjonesTACC - MdfNAit

The absolute value need: gen Mdf_abs_DACC $=a b s$ (MdfDACC)

The considerations and limitations to Modified Jones are similar to the Standard Jones model. First, regarding the decision to include or omit the constant term, zero intercept, the statistics literature shows necessarily a theoretical justification for no-intercept models. Second, estimation assumes that all variations in credit sales are due to earnings management practices (Paulo, 2007) and this is not always the case.

In addition, the Modified Jones overestimates discretionary provisions more than the Jones Standard (El Diri, 2017). As discussed, in relation to Standard Jones, for underdeveloped markets, as in the data used in our tutorial, if the industry sector and year approaches are used, there are problems related to the sample size, too small for the treatment and modeling adopted. 
Standard Jones and Modified Jones do not control for it, but theoretically and empirically, there is a relationship between accruals and the company's performance (past and contemporaneous). Kothari, Leone and Wasley (2005) develop the Modified Jones model controlling for the company's operational performance (El Diri, 2017); the model is known as the Modified Jones with return on assets.

\section{Modified Jones model with return on assets}

Kothari et al. (2005) improved the model by including an independent variable in the original model that captures the influence of the companies' past performance, as an attempt to control its impact on estimated discretionary accruals. Another important implementation by these authors is the formal inclusion of the intercept to improve the power of the estimates. Kothari et al. (2005) define:

$\operatorname{MJRT}_{i t}=\frac{\left(\Delta \text { non-cash Current Assets }_{i t}-\Delta \text { CurLiab }_{i t}+\Delta C P L T D_{i t}-D A E_{i t}\right)}{\text { Assets }_{t_{-} 1}}(6)$

where MJRTA $_{i t}=$ Modified Jones with ROA total accruals in year $t$ for firm $i$; $\Delta$ non - cash CurrentAssets ${ }_{i t}=$ changes in non-cash current assets in year $t$ for firm $i$; CurLiab $_{i t}=$ changes in current liabilities in year $t$ for firm $i$; $\triangle$ CPLTD $_{i t}$ $=$ changes in current portion of long-term debt in year $t$ for firm $i ; \mathrm{DAE}_{i t}=$ depreciation and amortization expense in year $t$ for firm $i$; and Assets t-1 $=$ total assets in year $t-1$ for firm $i$.

The variables CPLTD and STD correspond to the same item description. To calculate changes in non-cash current assets and the current portion of long-term debt in year $t$ for a company $i$ in our database, it is necessary to generate a new variable. We use the following command:

gen delta_noncash $=$ delta_current_assets - delta_cash

To estimate a Modified Jones model with return on assets (ROA), the procedure is similar to the Standard Jones and Modified Jones, including just the variable $\mathrm{ROA}_{i t}$ or $\mathrm{ROA}_{i t-1}$. ROA is a popular profitability metric used, and a particular problem is presented by Jewell and Mankin (2011): some versions are very divergent, influencing their comparability. We calculated ROA as the ratio of: (1) net income in a given year $t$ to total assets in year $t$; (2) net income in a given year $t$ to total assets in year $t-1$; and (3) net income in a given year $t$ to the mean of total assets between the years $t$ and $t-1$. It should be noted that these three calculated ROAs refer to the metric for the year $t$. The third option is used most often when the data are quarterly. To run: by Firm_id : gen ROA_1 = net_income / Assets

by Firm_id : gen ROA_2 = net_income /lag_Assets

by Firm_id : gen ROA_3 = net_income / ( Assets + lag_ Assets)/2)

And to generate $\mathrm{ROA}_{i t-1}$ we used the following commands:

$R O A \_1$ : by Firm_id : gen lag_ROA_1 $=I . R O A \_1$
$R O A \_2:$ by Firm_id : gen lag_ROA_2 $=I . R O A \_2$
$R O A$ 3: by Firm_id : gen lag_ROA_3 $=I . R O A \_3$

After generating the ROA variable, the next step is to estimate the regressions according to Equation 7:

$\operatorname{MJRT} A_{i t}=\delta_{0}+\delta_{1}\left(\frac{1}{A_{t-1}}\right)+\delta_{2} \Delta R_{i t}+\delta_{3} P P E_{i t}+\delta_{4} R O A_{i t(o r t-1)}+\epsilon_{i t}(7)$

To run all regressions, the steps follow previous explanation of Standard Jones and Modified Jones. However, Modified Jones with ROA rules out the use of the noconstant option in regressions to avoid the problems already discussed in the other subsections. In our database example, the command syntax to run all regression, first using one of the three definitions of ROA or lagged ROA, is:

bys B3_sector Year : asreg MJRTA InverseAT_jones 1991 delta Revenue_jones1991 PPE_jones1991 ROA_1, se fit

The Modified Jones model with ROA should be applied when performance is an important issue to control (Dechow, Ge, \& Schrand, 2010). Since the values of discretionary accruals are already registered by default in the variable_residuals, it is only necessary to transform the regression residuals into absolute values. According to the syntax used, it is only necessary to repeat steps already discussed in the subsection of Standard Jones. The syntax:

gen ROA_abs_DACC $=$ abs(_residuals)

Including performance in the model may cause a poor estimate, as the ROA can be correlated with other variables in the model and it can bias its coefficients (Keung \& Shih, 2014). Other controls for measured accruals are also proposed in other studies prior to Kothari et al. (2005). For example, McNichols (2002) and Dechow and Dichev (2002) argue that cash flow realizations in the period $t-1$ and subsequent periods in $t+1$ influence the quality of measured accruals. In addition, accruals may be predictors of cash flows and are related to it, since total accruals for a period can be reversed in later periods (Pae, 2005). 


\section{Modified Jones model considering cash flow and reversals}

The operationalization of the model considers cash flows and the reversion uses guidelines and variables previously discussed in other models. Total accruals follow Equation 3.
The steps are the same to generate the variables in Modified Jones subsection, since in the first part of the equation the calculation of total accruals is the same. The next step is to run the model in Equation 8, which is a combination of Standard Jones with cash flows and lagged accruals.

$$
\frac{T A_{i t}}{A_{i t-1}}=\alpha_{0}+\alpha_{1} \frac{1}{A_{i t-1}}+\beta_{1} \frac{\Delta R_{i t}}{A_{i t-1}}+\beta_{2} \frac{P P E_{i t}}{A_{i t-1}}+\beta_{3} \frac{C F O_{i t}}{A_{i t-1}}+\beta_{4} \frac{C F O_{i t-1}}{A_{i t-1}}+\beta_{5} \frac{T A_{i t-1}}{A_{i t-1}}+\epsilon_{i t}
$$

where $\mathrm{TA}_{i t}=$ total accruals in year $t$ for firm $i$, according to Equation $3 ; \Delta \mathrm{R}_{i t}=$ revenues in year $t$ less revenues in year $t-$ 1 for firm $i$; $\mathrm{PPE}_{i t}=$ gross fixed assets, plant, and equipment in year $t$ for firm $i$; $\mathrm{CFO}_{i t}=$ cash flow from operations in year $t$ for firm $i$; $\mathrm{CFO}_{i t-1}=$ cash flow from operations in year $t-1$ for firm $i$; $\mathrm{TA}_{i t-1}=$ total accruals in year $t-1$ for firm $i$, according to Equation 3; $\mathrm{A}_{i t-1}=$ total assets in year $t-1$ for firm $i$; and $\epsilon_{i t}=$ error term.

To estimate in Stata ${ }^{\circledR}$, without renaming the variables generated by default, the command is:

by Firm_id : gen lag_CFO $=$ I.CFO

by Firm_id : gen lag_ATPAE $=$ I.ATPAE

gen CFO_PAE $=$ CFO $/$ lag_Assets

gen lagCFO_PAE $=$ lag_CFO $/$ lag_Assets

gen lag_AT_PAE =lag_ATPAE /lag_Assets
After generating all these variables, we need to run the regressions using these new variables as in Equation 8:

bys B3_sector Year : asreg MdfjonesTACC InverseAT_ jones1991 delta_Revenue_jones1991 PPE_jones1991 CFO_ PAE lag_CFO_PAE lag_AT_PAE, se fit

And, finally, generate discretionary accruals by computing the absolute value of residuals:

gen PAE_abs_DACC = abs(_residuals)

When completing the operationalization of all stages of the models discussed, it is possible to generate a summary of the variables obtained. The syntax uses the asdoc command, as seen previously. Table 2 shows the average per year of the absolute value of each accrual and the standard deviation between parentheses. The syntax used on the command line is: asdoc by Year, sort : summarize wc_abs_DACC Mdf_abs_ $D A C C R O A$ abs_DACC PAE_abs_DACC, detail

Table 2. Example of summary statistics of absolute value of accruals variables performed.

\begin{tabular}{|c|c|c|c|c|c|c|c|c|c|}
\hline Variable & 2010 & 2011 & 2012 & 2013 & 2014 & 2015 & 2016 & 2017 & 2018 \\
\hline Jones & $\begin{array}{c}0.703 \\
(4.651)\end{array}$ & $\begin{array}{c}0.497 \\
(3.612)\end{array}$ & $\begin{array}{c}0.091 \\
(0.126)\end{array}$ & $\begin{array}{c}0.242 \\
(0.366)\end{array}$ & $\begin{array}{c}0.112 \\
(0.255)\end{array}$ & $\begin{array}{c}0.134 \\
(0.239)\end{array}$ & $\begin{array}{c}0.131 \\
(0.280)\end{array}$ & $\begin{array}{c}0.119 \\
(0.201)\end{array}$ & $\begin{array}{c}0.099 \\
(0.132)\end{array}$ \\
\hline Modified & $\begin{array}{c}2.289 \\
(23.83)\end{array}$ & $\begin{array}{c}0.346 \\
(5.203)\end{array}$ & $\begin{array}{c}0.005 \\
(0.014)\end{array}$ & $\begin{array}{c}0.002 \\
(0.004)\end{array}$ & $\begin{array}{c}0.006 \\
(0.007)\end{array}$ & $\begin{array}{c}0.014 \\
(0.016)\end{array}$ & $\begin{array}{c}0.008 \\
(0.014)\end{array}$ & $\begin{array}{c}0.006 \\
(0.008)\end{array}$ & $\begin{array}{c}0.004 \\
(0.006)\end{array}$ \\
\hline ROA & $\begin{array}{c}0.708 \\
(4.644)\end{array}$ & $\begin{array}{c}0.493 \\
(3.609)\end{array}$ & $\begin{array}{c}0.074 \\
(0.113)\end{array}$ & $\begin{array}{c}0.179 \\
(0.263)\end{array}$ & $\begin{array}{c}0.093 \\
(0.181)\end{array}$ & $\begin{array}{c}0.099 \\
(0.201)\end{array}$ & $\begin{array}{c}0.107 \\
(0.275)\end{array}$ & $\begin{array}{c}0.085 \\
(0.116)\end{array}$ & $\begin{array}{c}0.077 \\
(0.105)\end{array}$ \\
\hline PAE & - & $\begin{array}{c}0.126 \\
(0.147)\end{array}$ & $\begin{array}{c}0.072 \\
(0.114)\end{array}$ & $\begin{array}{c}0.190 \\
(0.205)\end{array}$ & $\begin{array}{c}0.101 \\
(0.197)\end{array}$ & $\begin{array}{c}0.084 \\
(0.102)\end{array}$ & $\begin{array}{c}0.098 \\
(0.183)\end{array}$ & $\begin{array}{c}0.101 \\
(0.142)\end{array}$ & $\begin{array}{c}0.077 \\
(0.109)\end{array}$ \\
\hline
\end{tabular}

Note. This table shows mean of each accrual variable and standard deviation in parentheses. Source: Costa, C. M., \& Soares, J. M. M. V. (2021). "Standard Jones and Modified Jones: An earnings management tutorial", Mendeley Data, V2, https://doi.org/10.17632/c939cpg956.2

When including the new variables, it is expected that, compared to the Standard Jones and the Modified Jones, the adjusted R2 will be mathematically higher. Formigoni, Antunes, and Paulo (2009) show that this is the main objective of the Pae (2005) model when including the natural reversals of accruals and the present and past cash flow. As in the other models presented, this model is also subject to criticism. Paulo (2007) highlights the possibility that the variables included in the model are subject to management, as in the other models. In view of what has already been discussed in other subsections, the conclusion regarding the Pae (2005) model, as well as the Standards Jones and its derivations (i.e., Dechow et al., 1995; Jones, 1991; Kothari et al., 2005), refers to one of the aphorisms highlighted by Box (2013): "all models are wrong, but some are useful” (Box, 2013, p. 162). 


\section{CONCLUSIONS}

We have introduced a step-by-step tutorial on accruals proxy used to measure earnings management. First, Standard Jones (Jones, 1991) model can be adopted and interpreted as a measure and a representation of earnings management by accruals. Second, the Modified Jones (Dechow et al., 1995) can be interpreted as being similar to Standard Jones and an improvement in earnings management accruals, more specifically in the discretionary part of accruals. Third, Modified Jones with ROA (Kothari et al., 2005) expands the accuracy of the metrics for performance control. Fourth, Modified Jones considering cash flow and reversals (Pae, 2005) includes reliability and avoid intrinsic problems of omitted variables, although it still carries theoretical simultaneity. Several reviews and validations (e.g., El Diri, 2017) consider the strength and usefulness of the models discussed.

Discretionary accruals are constantly used as a proxy to measure earnings management as a bad characteristic,

\section{REFERENCES}

Adams, J., Hayunga, D., Mansi, S., Reeb, D., \& Verardi, V. (2019). Identifying and treating outliers in finance. Financial Management, 48(2), 345-384. https://doi.org/10.1111/fima.12269

Adams, J. C., Mansi, S., Reeb, D. M., \& Wald, J. K. (2019). Cross-country outliers. Working Paper. http://dx.doi.org/10.2139/ssrn.3433186

Barghathi, Y., Collison, D., \& Crawford, L. (2018). Earnings management and audit quality: Stakeholders' perceptions. Journal of Management and Governance, 22(3), 629-659. https://doi.org/10.1007/s10997-017-9396-2

Barth, M., \& Taylor, D. (2010). In defense of fair value: Weighing the evidence on earnings management and asset securitizations. Journal of Accounting and Economics, $49(1$ 2), 26-33. https://doi.org/10.1016/j.jacceco.2009.10.001

Bergstresser, D., \&Philippon,T.(2006). CEO incentives and earnings management. Journal of Financial Economics, 80(3), 511529. https://doi.org/10.1016/j.jfineco.2004.10.011

Box, G. E. (2013). An accidental statistician: The life and memories of George EP Box. Hoboken, NJ: John Wiley \& Sons.

Camara, G. A., \& Galdi, F. C. (2013). Securitização como mecanismo de gerenciamento de resultados em bancos brasileiros. Revista de Contabilidade e Organizaçóes, 7(18), 14-24. https://doi.org/10.11606/rco.v7i18.55610 referring to opportunistic manipulation practices. As we discussed, due to the natural occurrence in the course of the companies' activities, management always occurs and in the most diverse ways. Omission of determinants in earnings management tests is a commonly encountered problem, because economic characteristics influence and are correlated with the determinants of earnings management (Dechow, Hutton, Kim, \& Sloan, 2012).

Many articles do not provide the database used, as they are often not necessarily public data, such as Compustat, Bloomberg, or Reuters. Our main contribution in this article was to establish a step-by-step tutorial so that future research can follow it and make the studies more comparable with each other when using these methods to measure earnings management. In addition, the propositions of the original models generally represent countries with developed capital markets. However, in developing markets, such as our database in Brazil, some forms of measurement may not provide the best results, requiring adaptations and tricks, as we discussed, to try to bring less noise, since all models have limitations and problems.
Caruso, G. D. Ferrari, E. R., \& Pisano, V. (2016). Earnings management and goodwill impairment: An empirical analysis in the Italian $M \& A$ context. Journal of Intellectual Capital, 17(1), 120-147. https://doi.org/10.1108/JIC-09-2015-0081

Coelho, A. C. D., \& Lopes, A. B. (2007). Avaliação da prática de gerenciamento de resultados na apuração de lucro por companhias abertas brasileiras conforme seu grau de alavancagem financeira. Revista de Administração Contemporânea, 11(esp. 2), 121-144. https://doi.org/10.1590/S1415-65552007000600007

Cornett, M. M., McNutt, J. J., \& Tehranian, H. (2009). Corporate governance and earnings management at large US bank holding companies. Journal of Corporate Finance, 15(4), 412-430. https://doi.org/10.1016/j.jcorpfin.2009.04.003

Costa, C. M., Matte, A. M., \& Monte-Mor, D. S. (2018). Endividamento e decisóes contábeis: A relação não linear entre dívida e qualidade dos lucros. Revista de Contabilidade e Organizaçôes, 12, e137077. https://doi.org/10.11606/issn.1982-6486.rco.2018.137077

Costa, C. M., \& Soares, J. M. M. V. (2021), "Standard Jones and Modified Jones: An earnings management tutorial", Mendeley Data, V2, https://doi.org/10.17632/c939cpg956.2 
Cox, N. (2006). WINSOR: Stata module to Winsorize a variable. Retrivied from https://econpapers.repec.org/software/ bocbocode/s361402.htm

Dechow, P. M., \& Dichev, I. D. (2002). The quality of accruals and earnings: The role of accrual estimation errors. The Accounting Review, 77(1), 35-59. Retrieved from https://www.jstor.org/stable/3203324

Dechow, P., Ge, W., \& Schrand, C. (2010). Understanding earnings quality: A review of the proxies, their determinants and their consequences. Journal of Accounting And Economics, 50(2-3), 344-401. https://doi.org/10.1016/j.jacceco.2010.09.001

Dechow, P., Hutton, A., Kim, J., \&Sloan, R. (2012). Detectingearnings management: A new approach, forthcoming. Journal of Accounting and Economics, 50(2), 275-334. https://doi.org/10.1111/j.1475-679X.2012.00449.x

Dechow, P. M., Sloan, R. G., \& Sweeney, A. P. (1995). Detecting earnings management. The Accounting Review, 70(2), 193225. Retrieved from https://www.jstor.org/stable/248303

De Jong, A., Mertens, G., Poel, M. V. D., \& Dijk, R. V. (2014). How does earnings management influence investor's perceptions of firm value? Survey evidence from financial analysts. Review of Accounting Studies, 19(2), 606-627. Retrieved from https://papers.ssrn.com/sol3/papers. cfm?abstract id $=2202294$

Dutzi, A., \& Rausch, B. (2016). Earnings management before bankruptcy: A review of the literature. Journal of Accounting and Auditing: Research \& Practice, 2016(2016), 1-21. http:// dx.doi.org/10.5171/2016.245891

Eisenhauer, J. G. (2003). Regression through the origin. Teaching statistics, 25(3), 76-80. https://doi.org/10.1111/1467-9639.00136

Eldenburg, L. G., Gunny, K. A., Hee, K. W., \& Soderstrom, N. (2011). Earnings management using real activities: Evidence from nonprofit hospitals. The Accounting Review, 86(5), 1605-1630. http://dx.doi.org/10.2308/accr-10095

El Diri, M. (2017). Introduction to earnings management. New York, NY: Springer Books.

Filip, A., \& Raffournier, B. (2014). Financial crisis and earnings management: The European evidence. The International Journal of Accounting, 49(4), 455-478. https://doi.org/10.1016/j.intacc.2014.10.004

Formigoni, H., Antunes, M. T. P., \& Paulo, E. (2009). Diferença entre o lucro contábil e lucro tributável: Uma análise sobre o gerenciamento de resultados contábeis e gerenciamento tributário nas companhias abertas brasileiras. Brazilian Business Review, 6(1), 44-61. http://dx.doi.org/10.15728/bbr.2009.6.1.3

Grecco, M. C. P. (2013). The Effect of Brazilian convergence to IFRS on earnings management by listed Brazilian nonfinancial companies. Brazilian Business Review, 10(4), 110-132. https://doi.org/10.15728/bbr.2013.10.4.5

Gull, A. A., Nekhili, M., Nagati, H., \& Chtioui, T. (2018). Beyond gender diversity: How specific attributes of female directors affect earnings management. The British Accounting Review, 50(3), 255-274. https://doi.org/10.1016/j.bar.2017.09.001
Gunny, K. A. (2010). The relation between earnings management using real activities manipulation and future performance: Evidence from meeting earnings benchmarks. Contemporary Accounting Research, 27(3), 855888. https://doi.org/10.1111/j.1911-3846.2010.01029.x

Hahn, G. J. (1977). Fitting regression models with no intercept term. Journal of Quality Technology, 9(2), 56-61. https://doi.org/10.1080/00224065.1977.11980770

Harris, O., Karl, J. B., \& Lawrence, E. (2019). CEO compensation and earnings management: Does gender really matters? Journal of Business Research, 98, 1-14. https://doi.org/10.1016/j.jbusres.2019.01.013

Healy, P. M., \& Wahlen, J. M. (1999). A review of the earnings management literature and its implications for standard setting. Accounting Horizons, 13(4), 365-383. https://doi.org/10.2139/ssrn.156445

Huang, X., Krishnan, S., \& Lin, P. (2018). Tone analysis and earnings management. Journal of Accounting \& Finance (21583625), 18(8). https://doi.org/10.33423/jaf.v18i8.110

Jewell, J. J., \& Mankin, J. A. (2011). What is your ROA? An investigation of the many formulas for calculating return on assets. Academy of Educational Leadership Journal, 15, 7991. Retrieved from http://ssrn.com/abstract=2155943

Jones, J. J. (1991). Earnings management during import relief investigations. Journal of Accounting Research, 29(2), 193228. https://doi.org/10.2307/2491047

Kalifekh, D. (2018). Cross-sectional analysis. Stata Forum. Retrieved from https://www.statalist.org/forums/forum/general-statadiscussion/general/1443035-cross-sectional-analysis

Kama, I., \& Weiss, D. (2013). Do earnings targets and managerial incentives affect sticky costs? Journal of Accounting Research, 51(1), 201-224. Retrieved from https:// onlinelibrary.wiley.com/doi/abs/10.1111/j.1475679X.2012.00471.x

Kang, S. H., \& Sivaramakrishnan, K. (1995). Issues in testing earnings management and an instrumental variable approach. Journal of Accounting Research, 33(2), 353-367. https://doi.org/10.2307/2491492

Keung, E., \& Shih, M. S. (2014). Measuring discretionary accruals: are ROA-matched models better than the original Jonestype models? Review of Accounting Studies, 19(2), 736-768. https://doi.org/10.1007/s11142-013-9262-7

Kothari, S. P. A, Leone, A. J., \& Wasley, C. E. (2005). Performance-matched discretionary accruals. Journal of Accounting \& Economics, 39(1), 163-197. https://doi.org/10.1016/j.jacceco.2004.11.002

Lin, B., Lu, R., \& Zhang, T. (2012). Tax-induced earnings management in emerging markets: Evidence from China. Journal of the American Taxation Association, 34(2), 19-44. http://dx.doi.org/10.2308/atax-10236

Liu, Y., Wei, Z., \& Xie, F. (2016). CFO gender and earnings management: Evidence from China. Review of Quantitative Finance and Accounting, 46(4), 881-905. https://doi.org/10.1007/s11156-014-0490-0 
Lo,K., Ramos, F., \&Rogo, R. (2017).Earningsmanagementandannual report readability. Journalof Accounting and Economics, 63(1), 1-25. https://doi.org/10.1016/j.jacceco.2016.09.002

Magro, C. B. D., Lavarda, C. E. F., \& Klann, R. C. (2019). Abordagens de estudos sobre gerenciamento de resultados: novas perspectivas a partir da análise bibliométrica. Revista Mineira de Contabilidade, 20(1), 34-49. https://doi.org/10.21714/2446-9114RMC2019v20n1t03

Martinez, A. L. (2011). The role of analysts as gatekeepers: enhancing transparency and curbing earnings management in Brazil. Revista de Administração Contemporânea, 15(4). https://doi.org/10.1590/S1415-65552011000400009

McNichols, M. F. (2002). Discussion of the quality of accruals and earnings: The role of accrual estimation errors. The Accounting Review, 77(1), 61-69. Retrieved from https://www.jstor.org/stable/3203325

Menicucci, E. (2020). Earnings quality and earnings management. In Earnings quality (pp. 53-82). London, UK: Palgrave.

Nardi, P. C. C., Silva, R. L. M. da, Nakao, S. H., \& Valle, M. R. do. (2009). A relação entre gerenciamento de resultados contábeis e o custo de capital das companhias abertas brasileiras. Revista Universo Contábil, 5(4), 06-26. http://dx.doi.org/10.4270/ruc.20095

Pae, J. (2005). Expected accrual models: the impact of operating cash flows and reversals of accruals. Review of Quantitative Finance and Accounting, 24(1), 5-22. https://doi.org/10.1007/s11156-005-5324-7

Parfet, W.U.(2000).Accountingsubjectivityandearningsmanagement: A preparer perspective. Accounting Horizons, 14(4), 481488. https://doi.org/10.2308/acch.2000.14.4.481

Paulo, E. (2007). Manipulação das informações contábeis: Uma análise teórica e empírica sobre os modelos operacionais de detecção de gerenciamento de resultados (Doctoral Thesis). Universidade de São Paulo, São Paulo.

Paulo, E., Martins, E., \& Corrar, L. J. (2007). Detecção do gerenciamento de resultados pela análise do diferimento tributário. Revista de Administração de Empresas, 47(1), 46-59. http://dx.doi.org/10.1590/S0034-75902007000100005

Peasnell, K. V., Pope, P. F., \& Young, S. (2000). Detecting earnings management using cross-sectional abnormal accruals models. Accounting and Business Research, 30(4), 313-326. http://dx.doi.org/10.1080/00014788.2000.9728949

Potharla, S. (2018). Earnings management modified jones model ols regression? Research Gate. Retrieved from https://www. researchgate.net/post/Earnings Management-Modified Jones Model-OLS regression

Qamhan, M. (2018). How to calculate (b0, b1, b2) in modified jones model? Research Gate. Retrieved from: https://www. researchgate.net/post/How to calculate b0 b1 b2 in Modified Jones Model 2
Richardson, S. A., Sloan, R. G., Soliman, M. T., \& Tuna, I. (2005). Accrual reliability, earnings persistence and stock prices. Journal of Accounting and Economics, 39(3), 437-485. https://doi.org/10.1016/j.jacceco.2005.04.005

Roychowdhury, S. (2006). Earnings management through real activities manipulation. Journal of Accounting and Economics, 42(3), 335-370. https://doi.org/10.1016/j.jacceco.2006.01.002

Shah, A. (2018). ASDOC: Stata module to create high-quality tables in MSWordfromStataoutput.Statisticalcomponents, S458466, Boston College Department of Economics. Retrivied from: https://ideas.repec.org/c/boc/bocode/s458466.html

Silva, A. D., Zonatto, V. C. D. S., Magro, C. B. D., \& Klann, R. (2019). Sticky costs behavior and earnings management. Brazilian Business Review, 16(2), 191-206. http://dx.doi.org/10.15728/bbr.2019.16.2.6

Silvestre, A. O., Costa, C. M., \& Kronbauer, C. A. (2018). Audit rotation and earnings quality: An analysis using discretionary accruals. Brazilian Business Review, 15(5), 410-426. https://doi.org/10.15728/bbr.2018.15.5.1

StataCorp, L. (2019). Stata: Release 16. statistical software. College Station, TX: StataCorp LP.

Sun, N., Salama, A., Hussainey, K., \& Habbash, M. (2010). Corporate environmental disclosure, corporate governance and earnings management. Managerial Auditing Journal, 25(7), 679-700. https://doi.org/10.1108/02686901011061351

Vasconcelos, C., Reis, D., Miyashiro, I., \& Paulo, E. (2008). A influência da cobertura das empresas de rating sobre o gerenciamento de resultados das companhias abertas brasileiras. Revista de Contabilidade e Organizaçóes, 2(3), 37-52. https://doi.org/10.11606/rco.v2i3.34712

Walker, M. (2013). How far can we trust earnings numbers? What research tells us about earnings management. Accounting and Business Research, 43(4), 37-41. http://dx.doi.org/10.1080/00014788.2013.785823

Xie, B., Davidson, W. N. III, \& DaDalt, P. J. (2003). Earnings management and corporate governance: The role of the board and the audit committee. Journal of Corporate Finance, 9(3), 295-316. https://doi.org/10.1016/S0929-1199(02)00006-8

Yu, F. F. (2008). Analyst coverage and earnings management. Journal of Financial Economics, 88(2), 245-271. https://doi.org/10.1016/j.jfineco.2007.05.008

Yu-jun, L. (2014). WINSOR2: Stata module to winsorize data. Statistical Software Components, S457765, Boston College Department of Economics. Retrieved from https://ideas.repec.org/c/boc/bocode/s457765.html

Zang, A. Y. (2012). Evidence on the trade-off between real activities manipulation and accrual-based earnings management. The Accounting Review, 87 (2), 675-703. http://dx.doi.org/10.2308/accr-10196 


\section{Authorship}

\section{Cristiano Machado Costa}

Universidade do Vale do Rio dos Sinos

Av. Dr. Nilo Peçanha, no 1600, Boa Vista, 91330-002, Porto

Alegre, RS, Brazil.

E-mail address: cristianocosta@unisinos.br

(D) https://orcid.org/0000-0001-9130-2562

\section{José Mauro Madeiros Velôso Soares*}

Universidade do Vale do Rio dos Sinos

Av. Dr. Nilo Peçanha, no 1600, Boa Vista, 91330-002, Porto

Alegre, RS, Brazil.

E-mail address: jose-mauro-m@hotmail.com

(D) https://orcid.org/0000-0002-9277-8316

* Corresponding Author

\section{Funding}

The authors reported that this study was financed in part by the Coordenação de Aperfeiçoamento de Pessoal de Nível Superior - Brazil (CAPES), Finance Code 001.

\section{Conflict of Interests}

The authors have stated that there is no conflict of interest.

\section{Copyrights}

RAC owns the copyright to this content.

\section{Peer Review Method}

This content was evaluated using the double-blind peer review process. The disclosure of the reviewers' information on the first page, as well as the Peer Review Report, is made only after concluding the evaluation process, and with the voluntary consent of the respective reviewers and authors.

\section{Authors' Contributions}

$1^{\text {st }}$ author: conceptualization (equal), data curation (equal), formal analysis (equal), funding acquisition (equal), investigation (equal), methodology (equal), project administration (lead), resources (equal), software (equal), supervision (lead), validation (equal), visualization (equal), writing-original draft (equal), writing-review \& editing (equal).

$2^{\text {nd }}$ author: conceptualization (equal), data curation (equal), formal analysis (equal), investigation (equal), methodology (equal), resources (equal), software (equal), writing-original draft (equal), writing-review \& editing (equal).

\section{Plagiarism Check}

The RAC maintains the practice of submitting all documents approved for publication to the plagiarism check, using specific tools, e.g.: iThenticate.

\section{Data Availability}

All data and materials have been made publicly available through the Harvard Dataverse platform and can be accessed at:

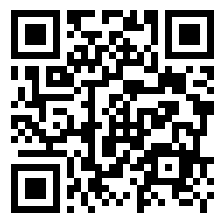

Costa, Cristiano Machado; Soares, José Mauro Madeiros Velôso, 2021, "Replication Data for: Standard Jones and Modified Jones: An Earnings Management Tutorial", Harvard Dataverse, V1. https://doi.org/10.7910/DVN/YDNPNO

RAC encourages data sharing but, in compliance with ethical principles, it does not demand the disclosure of any means of identifying research subjects, preserving the privacy of research subjects. The practice of open data is to enable the reproducibility of results, and to ensure the unrestricted transparency of the results of the published research, without requiring the identity of research subjects. 